\title{
Examine Design Considerations for Sustainable Management of an Overloaded Sewage Treatment Plant in a Residential Campus
}

\author{
Shiva Nandhini Sivakkumar, Karthikeyan Periysamy, Balaganesh Pandiyan, Natarajan \\ Narayanan, Vasudevan Mangottiri
}

\begin{abstract}
The era is now facing water scarcity and the available water is being depleted at a faster rate to meet the needs of the growing population. At this juncture, it is essential to use the reduce-reuse-recycle strategy. Reducing excessive usage of water for essential needs and reusing the recycled water for non-consumptive purposes can be a great step in the conservation of water. The waste water from various sources can be collected and treated using an STP. In most of the cases, water treatment requires a centralized system of control and operation. The STP should be designed by considering the inflow characteristics, objective of the water treatment and availability of resources. There are various operational and managerial constraints while designing an STP. In case of overloaded condition of available STP, either some modification has to be done to prevent the decrease in efficiency of the obtained output or a new plant has to be constructed. In this case study, we have analyzed three different approaches to solve the issue of an overloaded STP. The results based on various criteria including cost of construction and maintenance have been discussed.
\end{abstract}

Keywords: Sewage treatment plant; Sludge management; Wastewater characteristics; Design criteria

\section{INTRODUCTION}

$T_{\text {he trend of urbanization in India is creating enormous }}$ possibility to provide basic requirements such as safe drinking water, sanitation and infrastructure. The concurrent increase in the infrastructural facilities in our state not only largely demand more water but also produce large amount of wastewater. The modification of conventional treatment systems is therefore necessary to meet the timely requirement of safe handling of wastewater and to create ambient atmosphere in residential community [1-3]. The removal of organic matter by aerobic/anaerobic biodegradation is the

Revised Manuscript Received on December 05, 2019.

* Correspondence Author

Shiva Nandhini Sivakkumar*, Department of Civil Engineering, Bannari Amman Institute of Technology, Sathyamangalam, Erode, India Email: shivanandhini.ce17@bitsathy.ac.in

Karthikeyan Periysamy, Department of Civil Engineering, Bannari Amman Institute of Technology, Sathyamangalam, Erode, India. Email: karthikeyanp.ce17@bitsathy.ac.in

Balaganesh Pandiyan, Department of Civil Engineering, Bannari Amman Institute of Technology, Sathyamangalam, Erode, India. Email: balachem.aec@gmail.com

Natarajan Narayanan, Department of Civil Engineering, Dr. Mahalingam College of Engineering and Technology, Pollachi, India. Email: itsrajan2002@yahoo.co.in

Vasudevan Mangottiri, Department of Civil Engineering, Bannari Amman Institute of Technology, Sathyamangalam, Erode, India. Email: devamv@gmail.com most common technology adapted for small scale units. Recently, great advances have been made in the development of efficient technologies but challenges still remain.

The safe treatment of sewage is crucial to the health of any community. Operational efficiency is always of utmost importance in treatment facilities and this has driven innovation in the basic design and planning of these facilities. The design of sewage treatment plant (STP) for municipal wastewater treatment needs to address many issues such as varying influent parameters (quantity and quality), required treatment efficiency, energy consumption, excess sludge disposal methods etc. [4-5]. For e.g., the high water content of sludge may constitute a limitation for its beneficial use [6]. While thickening and dewatering can remove $7 \%$ and $35 \%$ of the total amount of water respectively, drying can remove up to $62 \%$ additional water content if applied in succession [7-8]. Similarly, in order to control the issues related to filter bed clogging and frequent backwashing operations, a pre-treatment step was adopted prior to the biological step, consisting of chemical precipitation by lime addition [9-10]. Many times, it is difficult to operate the plant with excess loading in terms of flow rate, volumetric BOD loading rate and suspended solids concentration. Therefore, it is important to understand the performance of an operating sewage treatment plant in a residential area to optimize the operating parameters in order to improve the effluent quality. The results of the present study will be highly beneficial for overcoming the operational difficulties in many small scale treatment plants existing in various residential units of educational institutions in our country.

\section{MATERIALS AND METHODS}

The study area is located at Sathyamangalam $\left(11.5048^{\circ} \mathrm{N}\right.$, $77.2384^{\circ} \mathrm{E}$ ), a municipality in Erode district of Tamil Nadu. It lies on the banks of River Bhavani and covered by Western Ghats in the south and east sides. The existing sewage treatment plant for the residents in the Bannari Amman Institute of Technology (BIT) has been operating for more than 15 years and is struggling to meet the treatment requirement due to the increased waste loading. The existing treatment plant consists of a collection tank, aeration tank, clarifier tank, filter units and sludge drying beds (Figure $1 \mathrm{a} \& \mathrm{~b})$. Presently about 12 lakh liters of wastewater is being generated from the hostels and mess. In addition to this, it is proposed to bring the wastewater from 133 staff quarters to the STP.

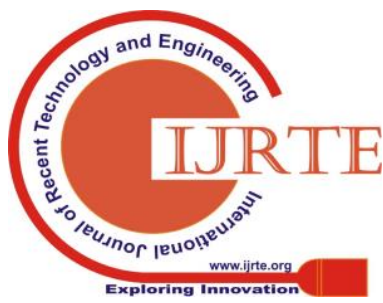


Therefore, some modification in the operation of the existing treatment plant is necessary in order to meet the daily waste management demand of the campus.

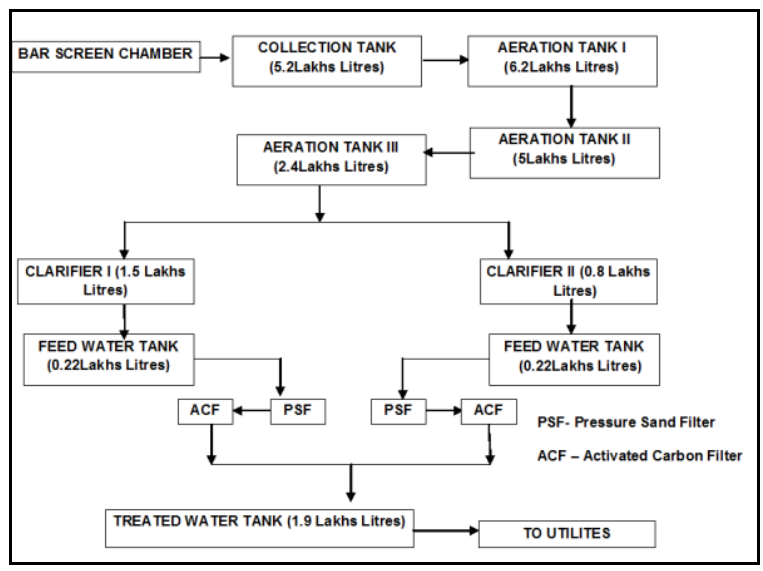

Fig. 1a. Layout of the existing STP at BIT Sathyamangalam

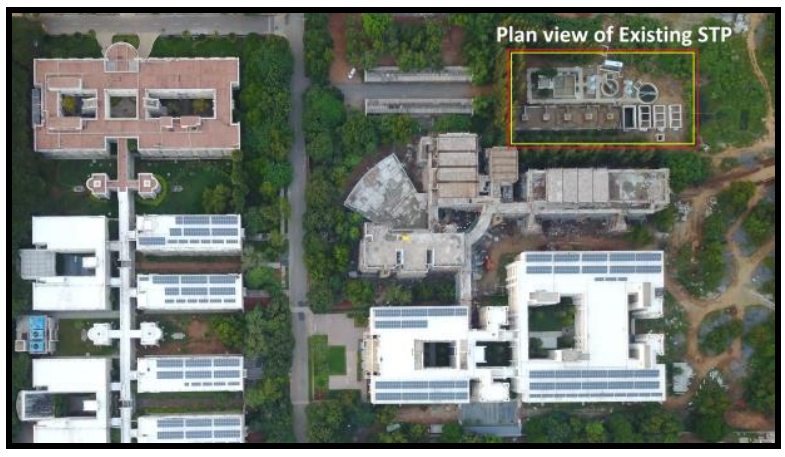

Fig. 1b. Drone image of the existing STP at BIT Sathyamangalam

Some of the basic details of the existing STP are collected from the design office and physical verification from the plant. The dimensions and capacity of each of these reactors (tanks) were cross-checked with the actual hydraulic loading rate and organic loading rate to evaluate the suitability of presently available residence time in each tank. Similarly, a few basic wastewater quality parameters were collected from various strategic points in the sewage flow line from generation to disposal, and were analysed regularly over a period of time.

\section{III. RESULTS AND DISCUSSION}

\section{A. Spatial and Temporal Variations in Wastewater characteristics}

The generated wastewater from hostels were initially fed to biogas production unit, which was further conveyed to the centralized treatment plant located at the lowest elevation point in the campus. Samples were collected from various points of wastewater generation and analyzed for important parameters like $\mathrm{pH}$, total dissolved solids (TDS), biochemical oxygen demand (BOD). Although daily average data of BD and TDS were marginally varying, the peak flow parameters indicated significant variations in the influent properties (Table 1). Since the preliminary anaerobic digestion was partial, the inflow to the collection tank of STP still had to handle high organic loading at least during the peak hours of the day. The impact of such an organic-rich inflow has resulted in incomplete aerobic digestion even after providing a safe residence time of 6hours in the activated sludge system [6]. This clearly indicated the inefficiency of the existing treatment plant to handle overloading situations.

Table- I: Important physico-chemical parameters indicating overloaded condition of STP

\begin{tabular}{|l|l|l|l|l|l|l|}
\hline \multirow{2}{*}{ Sample } & \multicolumn{3}{|c|}{ Daily average values } & \multicolumn{3}{|c|}{ Maximum values } \\
\cline { 2 - 7 } & $\boldsymbol{p H}$ & $\begin{array}{l}\mathbf{T D S} \\
(\boldsymbol{\mu} \mathbf{S} / \mathbf{c m})\end{array}$ & $\begin{array}{l}\text { BOD } \\
(\boldsymbol{m g} / \mathbf{L})\end{array}$ & $\boldsymbol{p H}$ & $\begin{array}{l}\boldsymbol{T D S} \\
(\boldsymbol{\mu} \mathbf{S} / \mathbf{c m})\end{array}$ & $\begin{array}{l}\boldsymbol{B O D} \\
(\boldsymbol{m g} / \mathbf{L})\end{array}$ \\
\hline $\begin{array}{l}\text { Boys Hostel } \\
\text { Biogas pump } \\
\text { off }\end{array}$ & 5.95 & 448 & 555 & 8.07 & 928 & 1950 \\
\hline $\begin{array}{l}\text { Boys Hostel } \\
\text { Biogas pump } \\
\text { on }\end{array}$ & 5.52 & 558 & 653 & 8.15 & 920 & 2303 \\
\hline $\begin{array}{l}\text { Ladies Hostel } \\
\text { Biogas Plant }\end{array}$ & 5.71 & 605 & 619 & 8.14 & 996 & 1663 \\
\hline $\begin{array}{l}\text { Ladies Hostel } \\
\text { Collection } \\
\text { Tank }\end{array}$ & 5.73 & 417 & 595 & 7.01 & 780 & 2524 \\
\hline STP Inlet & 6.16 & 475 & 617 & 7.55 & 720 & 1549 \\
\hline STP Outlet & 7.25 & 415 & 235 & 7.84 & 565 & 806 \\
\hline
\end{tabular}

Table 2 indicates the variation of physic-chemical parameters within the treatment plant during the sampling period. This clearly indicates the incomplete digestion of carbonaceous and nitrogenous compounds present in the influent. Although activated sludge process seems to be most promising, the limitations on reaction size, residence time and energy input highly constraints the treatment efficiency of purely aerobic systems.

Table- II: Important physico-chemical parameters indicating organic loading removal efficiency of STP

\begin{tabular}{|l|l|l|l|l|l|l|}
\hline Samples & $\begin{array}{l}\text { NO3 } \\
(\mathbf{m g} / \mathbf{L})\end{array}$ & $\begin{array}{l}\text { NO2 } \\
(\mathbf{m g} / \mathbf{L})\end{array}$ & $\begin{array}{l}\text { NH4 } \\
(\mathbf{m g} / \mathbf{L})\end{array}$ & $\begin{array}{l}\text { Chloride } \\
(\mathbf{m g} / \mathbf{L})\end{array}$ & $\begin{array}{l}\text { TOC } \\
(\mathbf{m g} / \mathbf{L})\end{array}$ & $\begin{array}{l}\text { TN } \\
(\mathbf{m g} / \mathbf{L})\end{array}$ \\
\hline $\begin{array}{l}\text { Collection } \\
\text { Tank }\end{array}$ & 44.3 & 69.2 & 0.54 & 2410.6 & 186.2 & 27.6 \\
\hline Sludge & 419.4 & 19 & 0.01 & 3970.4 & 10.9 & 2.4 \\
\hline Clarifier & 376.6 & 9 & 0.01 & 2127 & 11.5 & 3.3 \\
\hline
\end{tabular}

\section{B. Comparison of Various Technological Interventions to the Existing STP}

In order to modify the existing plant, various technological interventions were compared to achieve a more sustainable solution. If the existing plant were to be maintained at the same location, it is imperative to adopt a few infrastructural additions such as aeration and clarifier tank. However, due to the constraints on available space within the same premises, it is proposed to establish a few modifications away from the plant, but comes in line for the treatment. In this case, preliminary anaerobic digester (which is a modified version of existing biogas plants) could be installed and the effluent from the anaerobic digester can be fed to the aeration tank for further treatment $[8,10]$. This option seems to solve the current issue of withstanding capacity, but it will add up the expenditure required for additional pipelines and controls.

However, the most robust solution could be to install a completely new plant working on latest technology, which is independent of the current layout and suitable to relocate all sewage lines to the new plant. This option is envisaged to generate biogas from an initial anaerobic system, followed by aerobic system for quicker and efficient treatment. 
This idea seems to adopt latest technologies in wastewater treatment such as installation of an up-flow anaerobic sludge blanket (UASB) reactor, filter press for excess sludge dewatering and disinfection [9].

Table- III: Comparative statement of three different options for STP modification to treat 20 lakh litres per day

\begin{tabular}{|c|c|c|c|c|}
\hline Option & $\begin{array}{l}\text { Proposed } \\
\text { activity }\end{array}$ & $\begin{array}{l}\text { Estimated } \\
\text { installation } \\
\text { Cost (Rs.) }\end{array}$ & $\begin{array}{l}\text { Power } \\
\text { consumption/ } \\
\text { generation } \\
\text { rate } \\
\text { (units/day) }\end{array}$ & $\begin{array}{l}\text { Estimated } \\
\text { operational } \\
\text { cost (Rs.) }\end{array}$ \\
\hline $\begin{array}{l}\text { Up-grad } \\
\text { ation of } \\
\text { existing } \\
\text { STP }\end{array}$ & $\begin{array}{l}\text { Increase in } \\
\text { aeration } \\
\text { tank } \\
\text { capacity } \\
\text { and } \\
\text { additional } \\
\text { clarifier } \\
\text { tank }\end{array}$ & $\begin{array}{l}\text { Machinery } \\
=75 \text { Lakhs } \\
\text { Civil } \\
=70 \text { Lakhs } \\
\text { Total = } \\
1.45 \text { crores }\end{array}$ & $\begin{array}{l}\text { (Consumption) } \\
\text { Existing = } \\
1300 \text { units/ day } \\
\text { Additional = } \\
700 \text { units/ day } \\
\text { Total = 2000 } \\
\text { units/ day }\end{array}$ & $\begin{array}{l}\text { Existing = } \\
3,51,000 /- \\
\text { per month } \\
\text { Additional = } \\
1,89,000 /- \\
\text { per month } \\
\text { Total = } \\
5,40,000 /- \\
\text { per month }\end{array}$ \\
\hline $\begin{array}{l}\text { Addition } \\
\text { al } \\
\text { features } \\
\text { in new } \\
\text { location }\end{array}$ & $\begin{array}{l}\text { (a) } \\
\text { Anaerobic } \\
\text { digester } \\
\text { (b) Clarifier } \\
\text { tank } \\
\text { (c) Filter } \\
\text { press }\end{array}$ & $\begin{array}{l}\text { Machinery } \\
=1.3 \text { crores } \\
\text { Civil } \\
=2 \text { crores } \\
\text { Total = } \\
3.3 \text { crores }\end{array}$ & $\begin{array}{l}\text { Power } \\
\text { generation @ } \\
50 \text { Units/hour } \\
\text { with gas }\end{array}$ & $\begin{array}{l}\text { Saving of } \\
\text { Rs.2.5 } \\
\text { Lakhs/mont } \\
\text { h (Rs.30 } \\
\text { Lakhs/year) } \\
\text { Pay-back } \\
\text { period of } 11 \\
\text { years }\end{array}$ \\
\hline $\begin{array}{l}\text { New } \\
\text { STP at } \\
\text { new } \\
\text { location }\end{array}$ & $\begin{array}{l}\text { (a)UASB } \\
\text { (b) } \\
\text { Aeration } \\
\text { tank } \\
\text { (c) Filter } \\
\text { press }\end{array}$ & $\begin{array}{l}\text { Machinery } \\
=3 \text { crores } \\
\text { Civil } \\
=4 \text { crores } \\
\text { Total = } 7 \\
\text { crores }\end{array}$ & $\begin{array}{l}\text { Power } \\
\text { generation @ } \\
50 \text { Units/hour } \\
\text { with gas }\end{array}$ & $\begin{array}{l}\text { Saving of } \\
\text { Rs. } 2.5 \\
\text { Lakhs/mont } \\
\text { h } \\
\text { Pay-back } \\
\text { period of } 6 \\
\text { years }\end{array}$ \\
\hline
\end{tabular}

These three options were further subjectively compared in terms of economic feasibility based on the net expenditure and projected revenue generation from power production. As observed in Table 3, the selection of best alternative depends on the availability of resources such as land, money, power requirement as well as expected treatment efficiency. It is evident from the comparison that higher treatment efficiency and positive energy balance can be achieved with the third option, namely, new plant with advanced technology, though it seems to put some initial stress on the input resources such as land, equipment and capital cost. However, if the capital cost is insufficient, the next viable option can be the modification of existing layout with additional treatment units.

\section{Design Constraints and Future Opportunities}

The present exercise attempts to suggest alterative solutions addressing the complexities in decision making for an infrastructural design under multiple constraints. It is clear that the optimal solution (i.e. selection of alternative) depends on a number of internal and external factors. However, when sustainability is the required means and goal, it is important to take a holistic approach for a longer design period. In particular, though land availability and initial capital investment are the prominent constraints in first look, the third option overcome these with a higher sustainable goal in terms of the possibility of power production, efficient wastewater treatment and feasible recurring period. Under such constrained conditions, it is also advisable to install minor additional features such as hybrid aeration system with multiple aerators, changing recirculation ratio, improve filter media etc. to improve treatment efficiency of the existing plant for a longer period. There is ample opportunity to introduce automation in the design and operation of STPs working under constrained conditions to get more reliable and accurate data timely to take decisions on operation controls. The trend in design of STPs in the upcoming days are based on membrane-based aerobic system and energy-recovering hybrid systems. Hence it is imperative to adopt to sustainable steps in the primary design in order to avoid future modifications.

\section{CONCLUSION}

Present study deals with design considerations while selecting options for modifying an existing sewage treatment plant. The wastewater characteristics from various locations in the influent line as well as treatment units were evaluated to identify the treatment efficiency. An average outlet BOD of $235 \mathrm{mg} / \mathrm{L}$ indicated incomplete oxidation of organic matter due to the insufficient retention time. Similarly, the effluent from the biogas plants showed moderate strength (500-600 $\mathrm{mg} / \mathrm{L}$ on average) to produce biogas under extended anaerobic conditions. The results revealed that present treatment unit is unable to remove sufficient organic loading within given residence time. Hence three design options were compared to decide on the future modifications. The main constraints were observed to be the availability of land, availability of capital investment as well as energy requirement for a given standard of performance. However, on the sustainable point of view, new STP with latest technology can survive with surplus financial balance on a long run based on the expected power generation capacity. But it is also imperative to conclude that performance evaluation of existing STP can provide many useful insights on the possible modifications that can be incorporated without much financial stress on infrastructural requirements.

\section{ACKNOWLEDGMENT}

The authors wish to thank the students, staff and management of Bannari Amman Institute of Technology Sathyamangalam for their support in conducting this study.

\section{REFERENCES}

1. S. R. Qasim, "Wastewater treatment plants: planning, design, and operation", Routledge, 2017, 3rd Ed.

2. S. K. Garg and R. Garg, "Sewerage Disposal and Air Pollution Engineering: Environmental Engineering”, Khanna publishers; 1996.

3. P. Vesilind, "Wastewater treatment plant design", Eds., Vol. 2, IWA publishing, 2003.

4. M. A. Massoud, A. Tarhini, and J. A. Nasr, "Decentralized approaches to wastewater treatment and management: applicability in developing countries", J. Environ. Manage., 2009, vol. 90(1), pp.652-659.

5. E. Birol, and S. Das, "Estimating the value of improved wastewater treatment: The case of River Ganga, India”, J. Environ. Manage., 2010, vol. 91(11), pp.2163-2171.

6. H. Draaijer, J. A. Maas, J. E. Schaapman, and A. Khan, "Performance of the 5 MLD UASB reactor for sewage treatment at Kanpur, India", Water Sci. Tech., 1992, vol. 25(7), pp. 123-33. 
7. W. R. Abma, W. Driessen, R. Haarhuis, and M. C. Van Loosdrecht, "Upgrading of sewage treatment plant by sustainable and cost-effective separate treatment of industrial wastewater", Water Sci. Tech., 2010, vol. 61(7), pp. 1715-22.

8. M. Clara, N. Kreuzinger, B. Strenn, O. Gans, and H. Kroiss, "The solids retention time - a suitable design parameter to evaluate the capacity of wastewater treatment plants to remove micropollutants", Water Res. 2005, vol. 39(1), pp. 97-106.

9. N. Khalil, R. Sinha, A.K. Raghav and A. K. Mittal, "UASB technology for sewage treatment in India: experience, economic evaluation and its potential in other developing countries", In Twelfth Intl. Water Tech. Conf., pp. 1411-1427, August 2008.

10.P.A. Vanrolleghem, U. Jeppsson, J. Carstensen, B. Carlssont, and G. Olsson, "Integration of wastewater treatment plant design and operation - a systematic approach using cost functions", Water Sci. Tech., 1996, vol. 34(3-4), pp.159-171.

\section{AUTHORS PROFILE}

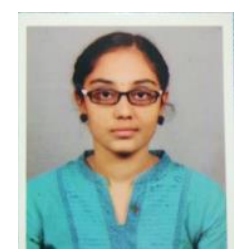

S Shiva Nandhini is currently pursuing her BE in Civil Engineering at Bannari Amman Institute of Technology Sathyamangalam, Tamil Nadu, India. She is interested in latest technologies in Civil Engineering including structural design and architecture.

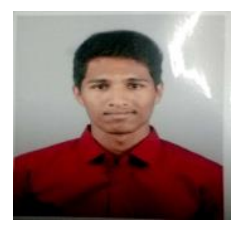

P Karthikeyan is currently pursuing his BE in Civil Engineering at Bannari Amman Institute of Technology Sathyamangalam, Tamil Nadu, India. He is interested in latest technologies in Construction Engineering including smart and eco-friendly materials.

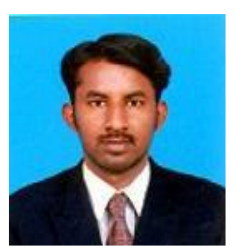

P Balaganesh is working as a Research Scholar in the Department of Civil Engineering at Bannari Amman Institute of Technology Sathyamangalam, Tamil Nadu, India. He obtained M.E. in Environmental Engineering M.A.M. College of Engineering (Anna University), Tamil Nadu, India. His areas of interest include solid waste management, wastewater treatment and bioenergy conversion.

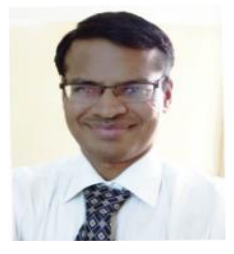

and modeling.

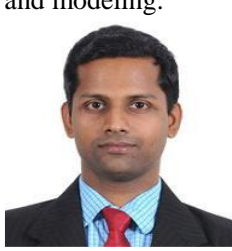

N Natarajan is working as Associate Professor in the Department of Civil Engineering at Dr. Mahalingam College of Engineering and Technology, Pollachi, Tamil Nadu, India. He obtained $\mathrm{PhD}$ in Water Resources (Civil) Engineering from Indian Institute of Technology Madras in 2012. He works in the area of environmental modeling and assessment, clean technology, groundwater contamination assessment

M Vasudevan is working as Assistant Professor in the Department of Civil Engineering at Bannari Amman Institute of Technology Sathyamangalam, Tamil Nadu, India. $\mathrm{He}$ obtained $\mathrm{PhD}$ in Environmental (Civil) Engineering from Indian Institute of Technology Madras in 2015. He works in the area of sustainable waste management, clean technology, groundwater contamination assessment and modeling. 